\title{
THE EFFECTS OF B CHROMOSOMES ON THE NUCLEAR PHENOTYPE IN ROOT MERISTEMS OF MAIZE
}

\author{
U. W. AYONOADU* and H. REES \\ Department of Agricultural Botany, University College of Wales, Aberystwyth, U.K.
}

Received 23.xii.70

\section{INTRODUCTION}

In Zea mays B chromosomes were first reported in sweet corn (Kuwada, 1915; Longley, 1927; Randolph, 1928; Avdulow, 1933; Humphrey, 1935), later in flint corn (Randolph, loc. cit.; Kozhuchow, 1933), flour corn (Longley, 1927, 1938), dent corn (Longley, loc. cit.; Kozhuchow, loc. cit.) and pop corn (Kozhuchow, loc. cit.). Longley (1938) also found B chromosomes in 14 out of 33 varieties of primitive maize varieties grown by North American Indians. The proportion of plants with B's varies between the varieties. Their effects upon the external phenotype are marked only when their numbers are high (15-20 B's). These effects tend to be of a "continuous" nature, very much like those due to polygenes (Muntzing, 1943, 1954, 1963; Mather, 1944; Lewis, 1950; McClintock, 1950; Brink, 1958).

The variation in the external phenotype due to B's must of course reflect upon the activity of the B's within the nuclei of cells. The purpose of the present work was to study the effects of B's directly upon the nuclear phenotype of somatic cells in an attempt to find out how the effects of B's upon development are brought about. The following nuclear characters were investigated:

(a) The size of the A chromosomes at mitosis.

(b) The nuclear DNA content of interphase nuclei.

(c) The nuclear dry mass, total protein, RNA and histone protein in interphase nuclei.

\section{MATERIAL AND MEthods}

\section{A. Material}

The material used was black Mexican sweet corn obtained from Dr E. B. Patterson of Illinois University to whom we are grateful.

\section{B. Methods}

Maize seedlings were grown together at $20^{\circ} \mathrm{C}$. in a culture bowl containing Hoagland's (1920) solution. The solution was changed at regular intervals. The seedlings were classified with respect to $B$ chromosome content by squashing root tips following immersion in 8-hydroxyquinoline and Feulgen staining.

\section{(i) Total chromosome volumes}

The total length of the chromosomes at metaphase was measured by means of a Vickers moving-scale micrometer eyepiece. Chromatid width was

* Present address: Bunda College of Agriculture, P.O. Box 219, Lilongwe, Malawi. 
measured in five chromosomes of the A complement at random and in all of the B chromosomes. The total chromosome volumes were estimated on the assumption that chromatids are cylindrical.

\section{(ii) Estimation of nuclear $D \mathcal{N} A$}

The staining procedure adopted was that described by McLeish and Sunderland (1961) and Sunderland and McLeish (1961). Roots from 0B and $8 \mathrm{~B}$ plants were fixed in neutral formaldehyde for 2 hours and washed in distilled water for 24 hours. The roots were then stained by the Feulgen method and photometric absorption measurements (at $560 \mathrm{~m} \mu$ ) were made on 2C telophase or early interphase nuclei using a Barr and Stroud integrating microdensitometer with a crushing condenser.

\section{(iii) Isolation of nuclei}

This technique is based on the method of McLeish (1963) with certain modifications by Evans (1968). Root tips from maize plants, grown in culture solution, were placed in ice cold $\mathrm{M} / 30$ phosphate buffer $(p \mathrm{H} 7 \cdot 0)$ containing 2 per cent. formaldehyde for 12 minutes. The terminal 2-3 mm. portion was tapped out in a drop of the buffer. The slides with isolated nuclei were flooded with absolute alcohol for 2 minutes, then placed in ether vapour in Coplin jars for 30 minutes. The dry slides were stored in Coplin jars until required.

\section{(a) Nuclear dry mass}

The mass of nuclei was determined, immediately after extraction and isolation, using the interference microscope. A full account of the theory of interference microscopy and its application to the measurements of mass are given by Barer (1956) and Davies (1958).

\section{(b) Total protein}

Extracted nuclei were immersed in 70 per cent. ethyl alcohol for 2 minutes, then absolute alcohol for 2 minutes and stained overnight in dinitrofluorobenzene $(\mathrm{DNFB})$ at $65^{\circ} \mathrm{C}$. Excess stain was removed by passing the slides through absolute alcohol to water and back again to absolute alcohol, cleared in xylene and then mounted in xam.

DNFB produces a bright yellow stain. The intensity of the stain and thereby the amount of total protein in isolated nuclei (see Mitchel, 1967) was estimated using an integrating microdensitometer. Measurements were made on seven B chromosome classes (0-6B) at a wavelength of $400 \mathrm{~m} \mu$.

\section{(c) Methyl-green-pyronin $Y$ stain for $R \mathcal{N A}$}

The method used was that described by Moss (1967). 1.5 g. of methyl green was dissolved in $300 \mathrm{ml}$. of $0.1 \mathrm{M}$ acetate buffer at $p \mathrm{H} 4.4$. The solution was extracted with chloroform to remove residual methyl violet (methyl violet interferes with RNA staining). Eight extractions may be necessary and extraction is stopped when the lower chloroform layer is colourless, i.e. it contains no methyl violet. $0.6 \mathrm{~g}$. of pronin $\mathrm{Y}$ was dissolved in this solution of methyl green.

Extracted nuclei were stained for 15 minutes and slides were rinsed in distilled water. They were then immersed in a differentiating solution of tertiary butyl alcohol $(3: 1)$ for 10 minutes-two 5-minute changes, cleared 
in xylene and mounted in a drop of glycerol. Photometric $(550 \mathrm{~m} \mu)$ measurements were made on a Barr and Stroud integrating microdensitometer and readings were taken from nine $\mathrm{B}$ chromosome classes $(0-8 \mathrm{~B})$.

The specificity of pyronin $\mathrm{Y}$ is checked by the use of a ribonuclease. Sample slides were treated with 0.1 per cent. ribonuclease solution (Type 1-A, sigma, London) at $40^{\circ}$ C. for $1 \frac{1}{2}$ hours (Moss, loc. cit.). The nucleoplasm stains a fainter green and the nucleolus a fainter reddish pink than the untreated slides.

\section{(d) Histone protein (fast green F.C.F. stain)}

Nucleic acids were removed from the tissue by treating the isolated nuclei in 5 per cent. solution of tri-chloro-acetic acid (TCA) in a warm-water bath at a temperature of $70-75^{\circ} \mathrm{C}$. for 30 minutes (see Alfert and Geshwind, 1953). A check that the DNA was removed is carried out by staining a sample slide with Feulgen. A negative result confirmed the total extraction of nucleic acids. Excess TCA was washed out by three 10 -minute changes in 70 per cent. ethyl alcohol.

Slides were stained for half an hour in 0.1 per cent. aqueous solution of the acid dye (Fast green F.C.F.-National Aniline Division, 96 per cent. dye content) adjusted to $p \mathrm{H} 8 \cdot 0-8 \cdot 1$ (at this $p \mathrm{H}$ range only histone proteins are stained) using $\mathrm{N} / 10 \mathrm{NaOH}$. A large volume $(800 \mathrm{ml}$.) of the stain was used to maintain the $p \mathrm{H}$ by reducing carbon dioxide absorption by the stain. Slides were thoroughly washed in distilled water to remove excess stain, dehydrated in 95 per cent. ethyl alcohol and absolute alcohol, both for 2 minutes, cleared in xylene and mounted in a drop of glycerol. Measurements were made on nine $\mathrm{B}$ chromosome classes $(0-8 \mathrm{~B})$ using the integrating microdensitometer and a light of wavelength $645 \mathrm{~m} \mu$.

\section{Results}

\section{(i) Chromosome volume}

Changes in the composition or in the organisation of chromosomes, such as may be due to the activity of B chromosomes, may, in certain circumstances, be expected to cause changes in chromosome size (see Jones and Rees, 1968; Bennett and Rees, 1969). Even a straightforward alteration in chromosome numbers may do so, e.g. polyploidy in Chrysanthemums (Dowrick, 1952) and Alliums (Sharma, 1965).

Three roots each of $0 \mathrm{~B}$ and $8 \mathrm{~B}$ plants were Feulgen stained after treatment in $0.002 \mathrm{M}$ 8-hydroxyquinoline and measurements were made in ten metaphases from each root. This makes a total of 30 readings for each class. A summary of the data is presented in table 1. Although the mean volumes for $\mathrm{A}$ chromosomes is higher for $\mathrm{OB}$ than $8 \mathrm{~B}$ plants, an analysis of variance on the replicate means showed no significant differences in chromosome volume between classes, nor were there any significant differences in lengths and average chromatid widths. In maize, therefore, the presence of $\mathrm{B}$ chromosomes has no overall effect on the size of the A chromosomes. This is in contrast to the results in rye where B's cause an increase in the volumes of the A chromosomes. Even in rye, however, there is no consistent increase in size relative to $\mathrm{B}$ frequency. Thus in $\mathrm{AB}$ and $\mathrm{BB}$ rye plants, the $\mathrm{A}$ chromosomes are of the same size (see Jones and Rees, loc. cit.), although the A chromo$\mathrm{s}$ omes in both classes are larger than in $\mathrm{OB}$ plants. 
TABLE 1

Summary of measurements of chromosome size at mitotic metaphase in maize plants with no $B$ and $8 B$ chromosomes

( $\mathrm{A}=\mathrm{A}$ chromosomes, $\mathrm{B}=\mathrm{B}$ chromosomes $)$

(a) Chromosome volume (cu. microns)

\begin{tabular}{llllll} 
& $\overbrace{\mathrm{A}}$ & $\mathrm{B}$ & & \multicolumn{2}{c}{} \\
Replicate 1 & 63.02 & - & 51.52 & 14.76 \\
Replicate 2 & 54.08 & - & 55.02 & 13.58 \\
Replicate 3 & 64.30 & - & 52.30 & 14.82 \\
Mean & 60.47 & - & 51.61 & 14.39
\end{tabular}

(b) Chromosome length (microns)

\begin{tabular}{|c|c|c|c|c|}
\hline & \multicolumn{2}{|c|}{ OB } & \multicolumn{2}{|c|}{$8 B$} \\
\hline & A & B & A & B \\
\hline Replicate 1 & $100 \cdot 33$ & - & $88 \cdot 16$ & $22 \cdot 88$ \\
\hline Replicate 2 & $110 \cdot 49$ & - & $87 \cdot 53$ & $21 \cdot 26$ \\
\hline Replicate 3 & 88.33 & - & $86 \cdot 32$ & $21 \cdot 84$ \\
\hline Mean & $98 \cdot 72$ & - & $87 \cdot 33$ & 21.99 \\
\hline
\end{tabular}

(c) Average chromatid width (microns)

\begin{tabular}{lllll} 
& $\overbrace{\mathrm{A}}$ & $\mathrm{B}$ & $\overbrace{\mathrm{A}}$ & \multicolumn{3}{c}{$8 \mathrm{~B}$} \\
Replicate 1 & 0.63 & - & 0.63 & 0.64 \\
Replicate 2 & 0.56 & - & 0.61 & 0.64 \\
Replicate 3 & 0.69 & - & 0.62 & 0.66 \\
Mean & 0.63 & - & 0.62 & 0.65
\end{tabular}

TABLE 2

Mean DNA amount (arbitrary units) in $2 C$ nuclei of maize plants without $B$ 's and with $8 B$ chromosomes

$\begin{array}{ccc}\text { Replicate } & \overbrace{0 \mathrm{~B}}^{2} \\ 1 & 9 \cdot 60 & 8 \mathrm{~B} \\ 2 & 9 \cdot 70 & 15 \cdot 10 \\ 3 & 11 \cdot 20 & 14 \cdot 00 \\ 4 & 10 \cdot 00 & 13 \cdot 60 \\ 5 & 10 \cdot 60 & 14 \cdot 90 \\ \text { Mean } & 10 \cdot 20 & 15 \cdot 20 \\ & & 14 \cdot 60 \\ \text { DNA content of A chromosomes } & =10 \cdot 20 \\ \text { DNA content of B chromosomes } & =4.40 \\ \text { DNA content per single B chromosome } & =0.55\end{array}$

(ii) Nuclear DNA estimates

The DNA was estimated in Feulgen-stained root tips from $0 \mathrm{~B}$ and $8 \mathrm{~B}$ plants. Readings were taken from ten $2 \mathrm{G}$ interphase nuclei in five roots (replicates) in each class. The data are presented in table 2. As we would 
expect, the DNA content of the nuclei increases in the presence of B's. The $8 \mathrm{~B}$ 's account for 4.4 units by which the $0 \mathrm{~B}$ and $8 \mathrm{~B}$ plants differ. In other words, more than 40 per cent. of the DNA in $8 \mathrm{~B}$ plants is attributable to the B's. Each B contributes 0.55 units of DNA, about 5 per cent. of the DNA content of all the A chromosomes.

B chromosomes in maize, as in other organisms, differ from the A's in a number of ways (see Longley, 1938; Randolph, 1941; Darlington and Upcott, 1941; Blackwood, 1956; Abraham and Smith, 1966). They are, for example, "relatively inert", carry no major genes and are not homologous with the A chromosomes in respect of pairing at meiosis. The present results show that these differences in their behaviour are associated with marked differences in their organisation at metaphase of mitosis. Table 3 shows that the DNA per unit volume is 1.7 times greater in B's than in

TABLE 3

$D \mathcal{N A}$ content (in arbitrary units) per unit volume in $A$ and $B$ chromosomes

\begin{tabular}{|c|c|c|c|c|}
\hline B class & & DNA & Volume & DNA/Volume \\
\hline $\mathrm{OB}$ & A & $10 \cdot 20$ & $60 \cdot 47$ & $0 \cdot 1687$ \\
\hline & B & - & 一 & - \\
\hline & A & $10 \cdot 20$ & $51 \cdot 61$ & $0 \cdot 1976$ \\
\hline $8 B$ & B & $4 \cdot 20$ & $14 \cdot 39$ & $0 \cdot 3058$ \\
\hline & & $\begin{array}{l}\text { or unit } \\
\text { or unit } \\
\text { or unit }\end{array}$ & $\begin{array}{l}\text { chromos } \\
\text { chromos } \\
\text { /A }\end{array}$ & $\begin{array}{l}0 \cdot 1832 \\
0 \cdot 3058 \\
1 \cdot 7\end{array}$ \\
\hline
\end{tabular}

A's. These findings are similar to those reported by Jones and Rees (loc. cit.) for B chromosomes in rye. They are also in line with the report of van Schaik and Pitout (1966) to the effect that the DNA in maize B chromosomes is four times greater per unit length than in A's. The greater DNA density of $\mathrm{B}$ chromosomes at metaphse is evidently a reflection of an allocycly characteristic of "inert" chromosomes and chromosome segments (see Darlington, 1965).

\section{(iii) The nuclear dry mass}

Measurements of the nuclear dry mass were made, like those of DNA content, in interphase nuclei. It is worth emphasising that whereas the amount of DNA is always directly related to the chromosome content we may expect the dry mass of the nucleus to vary independently of this. For example, variation displayed by the nucleolus during interphase will affect the total dry mass. Other, non-permanent, components within the nucleus may also vary in mass (Richards, 1960; Busch, Starbuck, Singh and Ro, 1964). In one sense, the addition of B's alone will increase the nuclear dry mass if only in respect of the permanent or structural components of the B's themselves, e.g. their DNA. Of particular interest, however, is whether the presence of B's affects the activity of the nucleus in such a way as to cause variation in the non-permanent components including, for example, the nucleolar RNA and non-permanent proteins. The measurements were made on 10 nuclei in roots of five plants (replicates) in each B class, from $0 \mathrm{~B}$ to $8 \mathrm{~B}$. The results are summarised in table 4 . 
TABLE 4

Mean dry mass (replicate means) of isolated $4 C$ nuclei in nine $B$ chromosome classes of Zea mays $\left(\times 10^{-11}\right.$ g.)

$\begin{array}{cccc}\text { Replicate } & \text { OB } & \text { 1B } & \text { 2B } \\ 1 & 5.808 & 7.697 & 10.288 \\ 2 & 5.858 & 7.508 & 9.853 \\ 3 & 6.039 & 7.459 & 9.485 \\ 4 & 5.934 & 7.489 & 9.790 \\ 5 & 5.974 & 7.244 & 9.628 \\ \text { Mean } & 5.923 & 7.479 & 9.809\end{array}$

(a) Total dry mass

$\begin{array}{cccccc}\text { 3B } & \text { 4B } & 5 \mathrm{~B} & 6 \mathrm{~B} & 7 \mathrm{~B} & 8 \mathrm{~B} \\ 8.483 & 10.125 & 7.938 & 8.671 & 7.538 & 7.497 \\ 8.693 & 10.455 & 8.015 & 8.571 & 7.478 & 8.717 \\ 8.926 & 10.431 & 8.165 & 8.720 & 7.089 & 7.943 \\ 8.696 & 10.379 & 8.009 & 9.197 & 7.338 & 8.063 \\ 8.902 & 10.312 & 8.194 & 9.589 & 7.534 & 8.081 \\ 8.740 & 10.340 & 8.064 & 8.950 & 7.395 & 8.060\end{array}$

\begin{tabular}{|c|c|c|c|c|c|c|c|c|c|}
\hline \multirow[b]{2}{*}{ Rep } & & \multirow[b]{2}{*}{$8 B$} \\
\hline & $\mathrm{OB}$ & 1B & $2 B$ & $3 B$ & $4 B$ & $5 B$ & $6 \mathrm{~B}$ & $7 B$ & \\
\hline 1 & 4.022 & 4.648 & $6 \cdot 486$ & $5 \cdot 554$ & 6.597 & 5.480 & $5 \cdot 750$ & 4.705 & 4.929 \\
\hline 2 & $4 \cdot 180$ & 4.687 & 6.313 & 5.478 & 6.671 & 5.405 & 5.554 & $4 \cdot 609$ & 5.476 \\
\hline 3 & $4 \cdot 100$ & 4.924 & 6.285 & 5.730 & 6.728 & 5.447 & 5.955 & $4 \cdot 564$ & 5.030 \\
\hline 4 & $4 \cdot 155$ & $4 \cdot 774$ & 6.405 & 5.486 & 7.041 & 5.538 & $6 \cdot 147$ & 4.545 & $5 \cdot 145$ \\
\hline 5 & $4 \cdot 233$ & 4.828 & 6.285 & 5.757 & 6.810 & $5 \cdot 392$ & $6 \cdot 363$ & 4.585 & 5.085 \\
\hline Mean & $4 \cdot 138$ & $4 \cdot 772$ & 6.355 & 5.601 & $6 \cdot 767$ & $5 \cdot 452$ & 5.954 & $4 \cdot 602$ & $5 \cdot 133$ \\
\hline
\end{tabular}

\begin{tabular}{cccccccccc} 
& \multicolumn{8}{c}{ (c) Nucleolus dry mass } \\
Replicate & 0B & IB & 2B & 3B & 4B & $5 \mathrm{~B}$ & $6 \mathrm{~B}$ & $7 \mathrm{~B}$ & $8 \mathrm{~B}$ \\
1 & 1.786 & 3.050 & 3.820 & 2.928 & 3.528 & 2.458 & 2.921 & 2.833 & 2.569 \\
2 & 1.678 & 2.822 & 3.540 & 3.215 & 3.784 & 2.610 & 3.017 & 2.869 & 3.241 \\
3 & 1.939 & 2.535 & 3.200 & 3.196 & 3.703 & 2.718 & 2.766 & 2.525 & 2.913 \\
4 & 1.779 & 2.715 & 3.383 & 3.210 & 3.338 & 2.471 & 3.050 & 2.793 & 2.918 \\
5 & 1.742 & 2.416 & 3.343 & 3.145 & 3.503 & 2.802 & 3.226 & 2.949 & 2.996 \\
Mean & 1.785 & 2.708 & 3.458 & 3.139 & 3.571 & 2.612 & 2.996 & 2.794 & 2.927
\end{tabular}

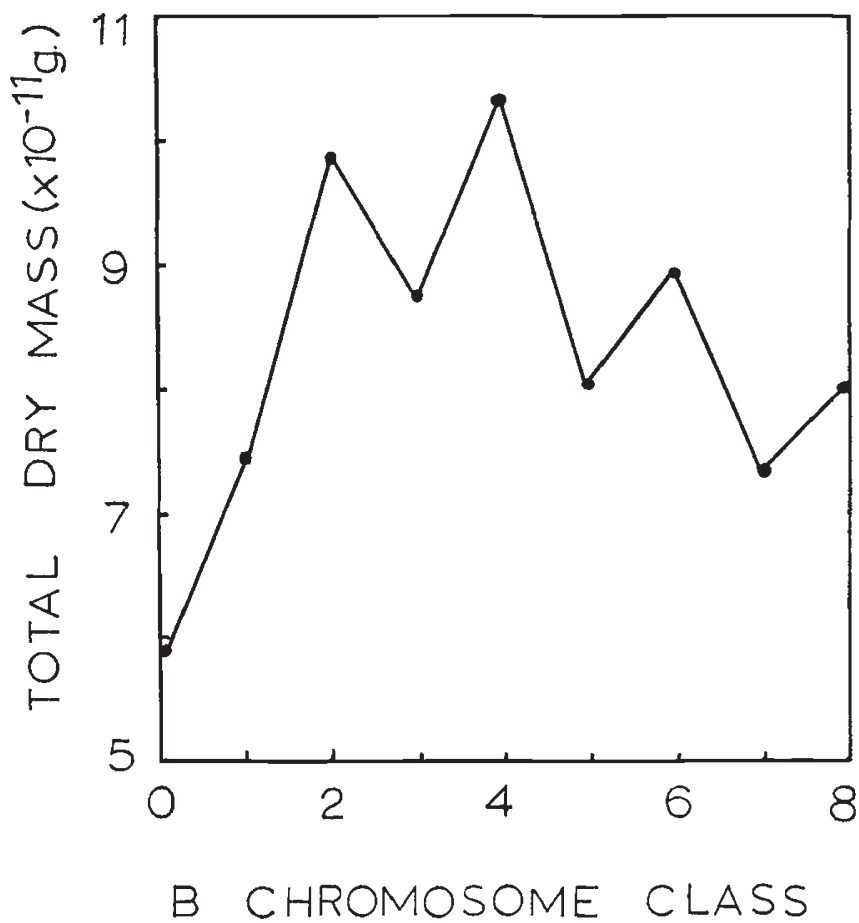

Fig. 1.--Mean total dry mass (T.D.M.) of isolated 4 C nuclei $\left(\times 10^{-11}\right.$ g.), plotted against B chromosome class. 
(a) The total dry mass (T.D.M.)

The results in table $4 a$ and in fig. 1 show that the variation in the total dry mass of the nucleus does not increase in simple, direct proportion to the B frequency. Nevertheless there are highly significant differences between classes (table $5(a)$ ). What is particularly striking is the disproportionately high nuclear mass values for even-numbered B classes, namely $2 \mathrm{~s}, 4 \mathrm{~s}, 6 \mathrm{~s}$ and 8s. This consistent "zig-zag" pattern is of exactly the same kind as that reported in rye (Jones and Rees, loc. cit.). Such a pattern, of course, cannot possibly be explained on the basis of a direct contribution of that component of $\mathrm{B}$ chromosomes which is permanent. As in rye, the variation may be

TABLE 5

Analyses of variance of differences in total dry mass, nucleus dry mass and nucleolus dry mass in nine $B$ chromosome classes of maize

\begin{tabular}{|c|c|c|c|c|c|}
\hline \multicolumn{6}{|c|}{ (a) Total dry mass } \\
\hline Item & S.S. & d.f. & M.S. & V.R. & $\mathbf{P}$ \\
\hline Classes & 71.558 & 8 & 8.944 & $135 \cdot 515$ & $<0.001$ \\
\hline Error & $2 \cdot 300$ & 36 & 0.066 & - & - \\
\hline Total & $73 \cdot 948$ & 44 & $一$ & - & - \\
\hline \multicolumn{6}{|c|}{ (b) Nucleus dry mass } \\
\hline Item & S.S. & d.f. & M.S. & V.R. & $\mathbf{P}$ \\
\hline Classes & $29 \cdot 928$ & 8 & 3.741 & $133 \cdot 607$ & $<0.001$ \\
\hline Error & $1 \cdot 026$ & 36 & 0.028 & 一 & - \\
\hline Total & 30.954 & 44 & - & - & - \\
\hline \multicolumn{6}{|c|}{ (c) Nucleolus dry mass } \\
\hline Item & S.S. & d.f. & M.S. & V.R. & $\mathbf{P}$ \\
\hline Classes & $11 \cdot 010$ & 8 & 1.376 & $41 \cdot 696$ & $<0.001$ \\
\hline Error & $1 \cdot 210$ & 36 & 0.033 & - & - \\
\hline Total & $12 \cdot 220$ & 44 & - & - & - \\
\hline
\end{tabular}

explained in terms of non-permanent nuclear components which, in turn, vary as a consequence of the influence of $\mathrm{B}$ chromosomes upon the metabolism of the nucleus.

When we consider the ratios of the total dry mass to DNA (T.D.M./DNA) for the nine B classes (Table 6 and fig. 2) it will be seen that from 1 to $8 \mathrm{~B}$ the T.D.M./DNA values decrease. In short, the mass of the nucleus per unit of DNA decreases with increasing $B$ frequency. We note also that the total dry mass is particularly low per unit of DNA in the odd-numbered B classes. The implications of these observations will be considered later. In the meantime the results show convincingly that $\mathrm{B}$ chromosomes have a marked influence upon the phenotype of root-tip interphase nuclei in respect of their total mass. Below is an attempt to find out which components within the nucleus contribute to this variation in dry mass.

(b) The nucleolus dry mass

Data for the dry mass of the nucleolus alone are presented in table $4(c)$ and in fig. 3. An analysis of variance (table $5(c)$ ) shows significant differences between classses $(P=<0.001)$. As can be seen from the figure, there 
TABLE 6

The DNA content (arbitrary units), mean total dry mass (T.D.M.) $\left(\times 10^{-11} \mathrm{~g}.\right)$ and the T.D.M./DNA ratio in nine $B$ chromosome classes

\begin{tabular}{|c|c|c|c|}
\hline B classes & DNA & T.D.M. & T.D.M./DNA \\
\hline OB & $10 \cdot 20$ & 5.92 & 0.58 \\
\hline 1B & $10 \cdot 80$ & 7.48 & 0.73 \\
\hline $2 B$ & $11 \cdot 30$ & 9.81 . & 0.87 \\
\hline $3 B$ & 11.90 & 8.74 & 0.73 \\
\hline $4 B$ & $12 \cdot 40$ & $10 \cdot 34$ & 0.83 \\
\hline $5 B$ & 13.00 & 8.06 & 0.62 \\
\hline $6 \mathrm{~B}$ & 13.50 & 8.95 & 0.66 \\
\hline $7 \mathrm{~B}$ & $14 \cdot 10$ & $7 \cdot 40$ & 0.52 \\
\hline $8 B$ & 14.60 & 8.06 & 0.55 \\
\hline
\end{tabular}

The DNA per $\mathrm{B}$ chromosome was derived by the method described in table 3 .

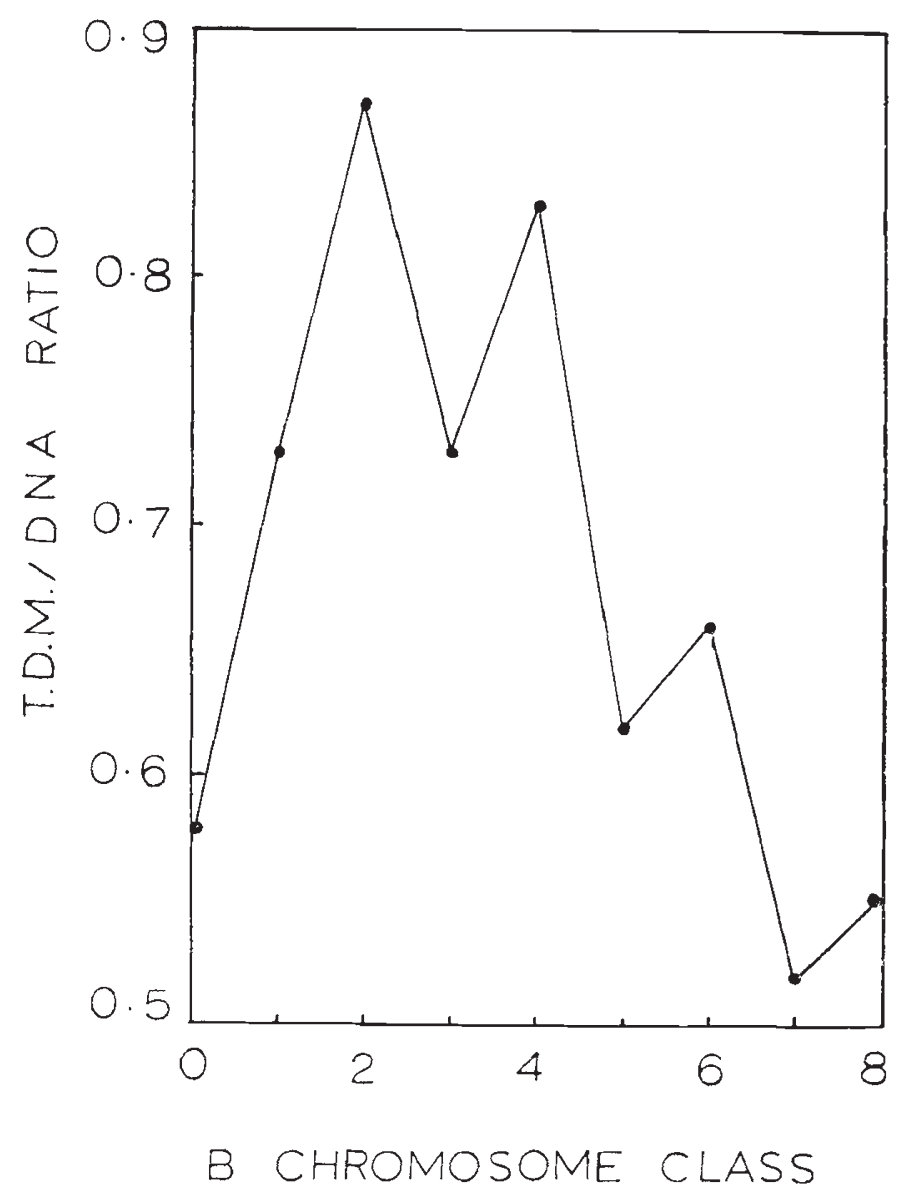

Frg. 2.-The T.D.M./DNA ratio plotted against $B$ chromosome class.

is an overall increase in the nucleolus dry mass with increasing B frequency. Although the values for the higher B classes show a tendency to drop the values for all $\mathrm{B}$ chromosome classes are greater than those for normal plants. These results agree, in part, with the findings of Lin (1955). He reported 
a 2.3 per cent. increase in nucleolar RNA with the addition of each extra $\mathrm{B}$ chromosome. The present results indicate, as has already been mentioned, that the rate of increase in nucleolar material falls off with the addition of high numbers of B's.

(c) The nucleus dry mass (excluding the nucleolus)

The nucleus dry mass is made up mainly of the chromosomes but, in addition, of products of chromosome activity excluding those contained in the nucleolus. The data for the nucleus dry mass appear in table 4 (b) and in fig. 4. As can be seen from the figure, the dry mass of the nucleus increases

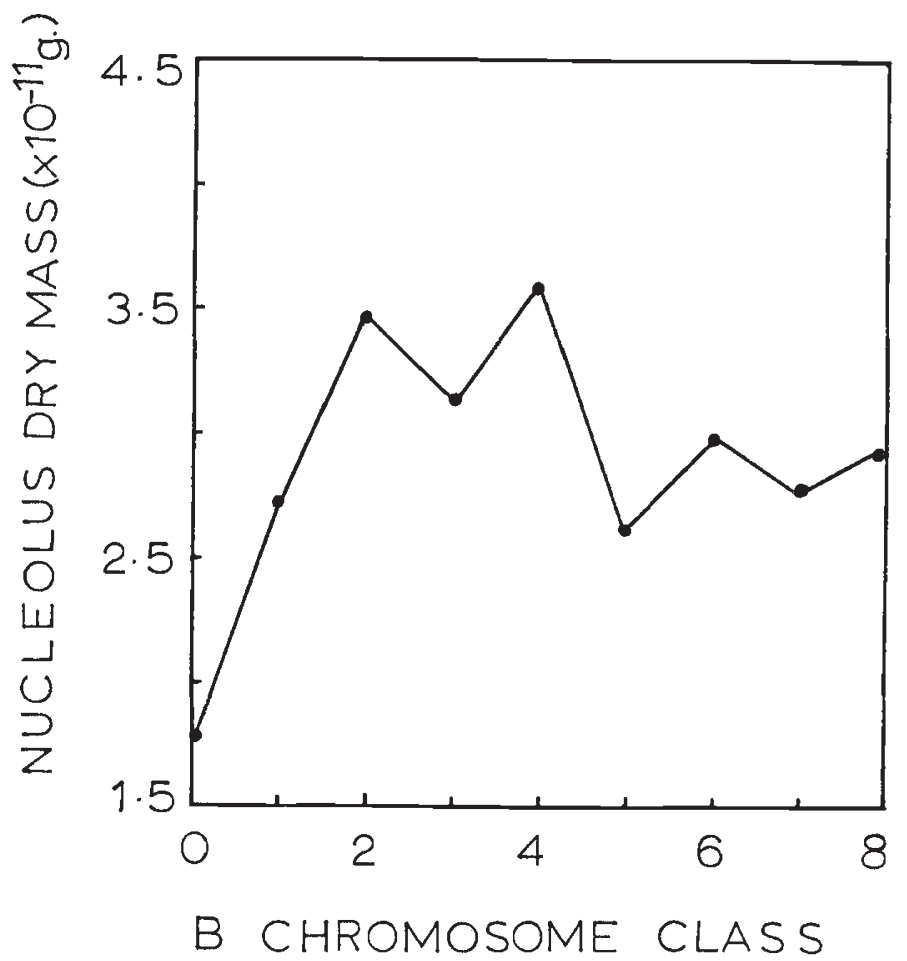

Fig. 3.-Mean nucleolus dry mass of isolated $4 \mathrm{C}$ nuclei $\left(\times 10^{-11} \mathrm{~g}.\right)$, plotted against $B$ chromosome class.

with increasing $B$ frequency and an analysis of variance on the replicate means, table $5(b)$, confirms significant differences between classes, with the same disproportionate increases in the values for even numbered $\mathrm{B}$ classes reported in earlier sections.

In order to determine what chemical components of the nucleus are responsible for this variation the DNA values (table 6) were transformed to absolute units (grams). The transformation was achieved by determining simultaneously the 2C DNA amount in maize and in Allium cepa, whose DNA value is $33.55 \times 10^{-12} \mathrm{~g}$. (van't Hof, 1965). By subtracting the absolute DNA amounts from the mass of the nucleus we can then deal separately with the non-DNA component (see table 7 and fig. 4). 
The increase in DNA must, of course, be directly proportional to the B frequency. As for the non-DNA component we observe, in general, an increase up to $6 \mathrm{~B}$ followed by a rapid decrease. Clearly the variation in the nucleus dry mass cannot be explained simply in terms of the addition of permanent B chromosome components. Non-permanent nuclear components must be implicated. In particular, they decrease beyond $6 \mathrm{~B}$ and, equally clearly, they are disproportionately low in odd-numbered B classes. This

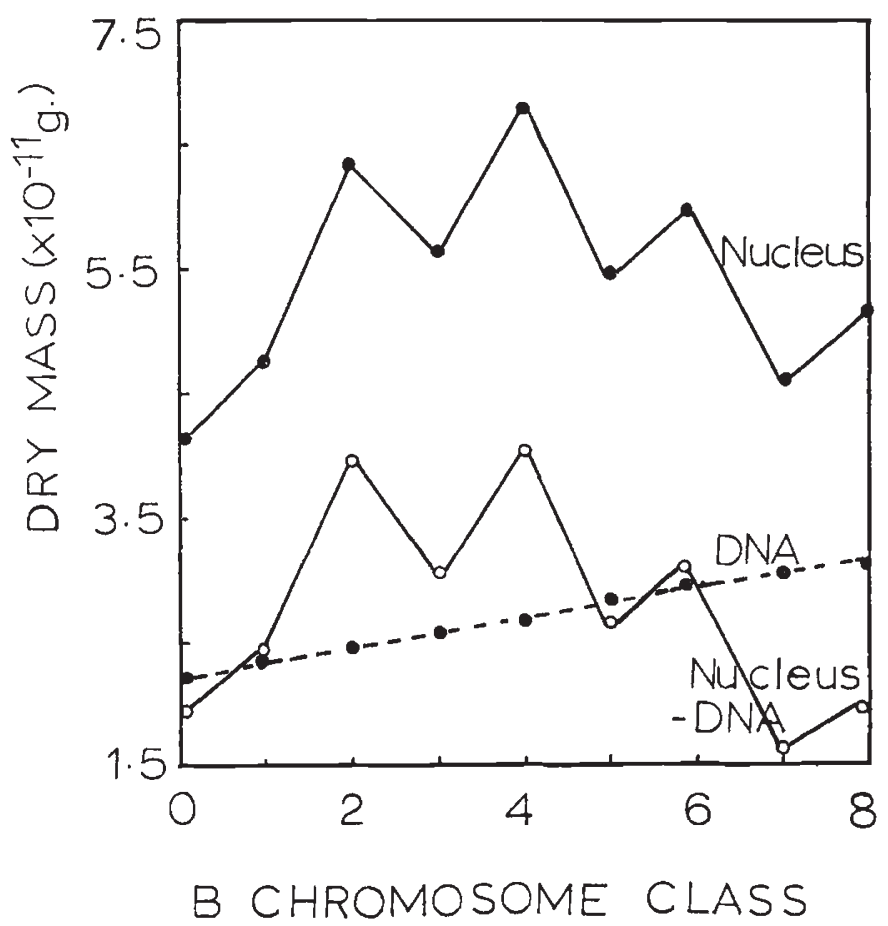

Fig. 4.-Mean nucleus dry mass nucleus minus DNA $O$

, mean calculated DNA

....

mass of

TABLE 7

The mean DNA amount, the nucleus dry mass and the mass of the nucleus other than DNA (4C values, all

\begin{tabular}{lccccccccc}
\multicolumn{1}{c}{$\times 1$ B class } & $0 \mathrm{~B}$ & $1 \mathrm{~B}$ & $2 \mathrm{~B}$ & $3 \mathrm{~B}$ & $4 \mathrm{~B}$ & $5 \mathrm{~B}$ & $6 \mathrm{~B}$ & $7 \mathrm{~B}$ & $8 \mathrm{~B}$ \\
DNA & 2.20 & 2.32 & 2.44 & 2.56 & 2.68 & 2.80 & 2.92 & 3.04 & 3.15 \\
Nucleus dry mass & 4.14 & 4.77 & 6.36 & 5.60 & 6.77 & 5.45 & 5.95 & 4.60 & 5.13 \\
Nucleus-DNA & 1.94 & 2.45 & 3.92 & 3.04 & 4.09 & 2.65 & 3.03 & 1.56 & 1.96
\end{tabular}

variable component reflects the influence of $\mathrm{B}$ chromosomes on nuclear products. These products would appear to be extra chromosomal because it will be recalled that chromosome size remains unchanged with varying $B$ frequency (see table 1 ). In the following sections an attempt is made to measure some of the important variable components, namely nuclear RNA, total protein and histone.

\section{(iv) Nuclear RNA}

Isolated nuclei were stained for 15 minutes in methyl-green-pyronin $\mathrm{Y}$ and photometric measurements (at $550 \mathrm{~m} \mu$ ) were made on nine B chromo- 
some classes (0-8B). There were three replicates in each class. The data are presented in table 8 and fig. 5. Also included are the RNA/DNA ratios

TABLE 8

Nuclear RNA amounts (arbitrary units) in nine $B$ chromosome classes of maize and their corresponding $R \mathcal{N} A / D \mathcal{N} A$ ratios

$\begin{array}{cccccc}\text { B class } & \text { Replicate } & \text { Replicate } 2 & \text { Replicate } 3 & \text { Mean } & \begin{array}{c}\text { RNA/DNA } \\ \text { ratio }\end{array} \\ \text { 0B } & 7.13 & 6.47 & 7.20 & 6.93 & 0.68 \\ \text { 1B } & 7.77 & 7.43 & 7.83 & 7.68 & 0.75 \\ \text { 2B } & 11.33 & 10.40 & 10.30 & 10.68 & 0.95 \\ \text { 3B } & 9.93 & 9.93 & 9.43 & 9.76 & 0.82 \\ \text { 4B } & 13.40 & 12.50 & 11.53 & 12.44 & 1.00 \\ \text { 5B } & 9.07 & 9.07 & 9.17 & 9.10 & 0.70 \\ \text { 6B } & 10.23 & 10.13 & 10.23 & 10.19 & 0.75 \\ \text { 7B } & 7.97 & 8.23 & 8.43 & 8.21 & 0.58 \\ \text { 8B } & 8.67 & 8.50 & 8.73 & 8.63 & 0.59\end{array}$

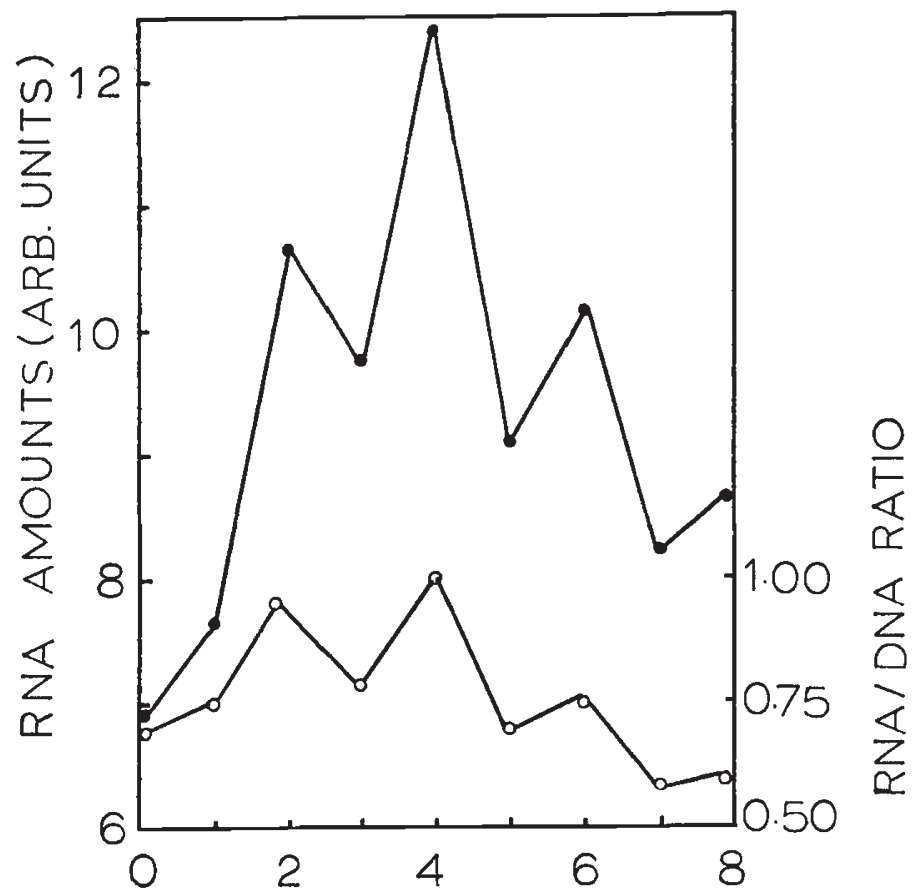

B CHROMOSOME CLASS

FIG. 5.-RNA amounts (arbitrary units) —— and the corresponding RNA/DNA ratios $\mathrm{O}-\mathrm{O}$ plotted against $\mathrm{B}$ chromosome class.

for the different classes. It is clear from the figure that the RNA values increase with increasing $B$ frequency and an analysis of variance on the replicate means, table 9 confirms significant differences between classes $(\mathrm{P}=<0.001)$. However, this increase is not consistent for all classes. There are marked differences between the even and odd numbers of B chromosomes. 
These findings confirm, to some extent, Lin's (loc. cit.) findings. He measured nucleolar RNA in plants without and with $8 \mathrm{~B}$ chromosomes and found a difference of 18 per cent. in the RNA amounts. He concluded, therefore, that each additional B chromosome increased the nucleolar RNA by 2.3 per cent., but as shown in the present results the increase in RNA is not directly proportional to $\mathrm{B}$ class nor is this increase maintained indefinitely. Hime's (1967) results on the face of it contradict the present findings

TABLE 9

Analysis of variance of differences in $R N A$ amounts in nine $B$ chromosome classes of maize

\begin{tabular}{lrrlcc}
\multicolumn{1}{c}{ Item } & S.S. & d.f. & M.S. & V.R. & P \\
Classes & 66.73 & 8 & 8.34 & 47.93 & $<0.001$ \\
Error & 3.13 & 18 & 0.174 & - & - \\
Total & 69.86 & 26 & - & - & -
\end{tabular}

and those of Lin's. She compared the rates of RNA synthesis (by autoradiography) in maize nuclei with $15-20 \mathrm{~B}$ chromosomes and maize nuclei without B's. She found that the addition of B chromosomes had no effect on the synthesis of nucleolar RNA. Figure 5 shows, however, that Hime's results are not necessarily incompatible with those in the present work. The figure shows a drop in nuclear RNA with increasing $B$ frequency beyond $4 \mathrm{~B}$ 's, and it is quite possible that the nuclear RNA is no greater in $15 \mathrm{~B}$ plants than in $0 \mathrm{~B}$ plants.

\section{(v) Total protein}

Changes in nuclear protein are characteristic consequences, or even causes, of development and differentiation (see Brown, 1963). They could also reflect short-term trends such as loss of chromosomal protein between prophase and metaphase (Caspersson, 1947, 1950; Swift, 1953). In contrast, the nuclear DNA amount per chromosome is constant. Variation in total protein content, therefore, is at least partly independent of variation in DNA (Bennett and Rees, loc. cit.; Leuchtenberger and Schrader, 1952; Bachman and Cowden, 1965).

TABLE 10

Total nuclear protein (arb. units) in seven B chromosome classes of maize and their corresponding protein $/ D \mathcal{N} A$ ratios

$\begin{array}{ccc}\text { B class } & \text { Total protein } & \text { Protein/DNA ratio } \\ \text { 0B } & 13.74 & 1.35 \\ \text { 1B } & 14.74 & 1.38 \\ \text { 2B } & 17.08 & 1.51 \\ \text { 3B } & 14.82 & 1.24 \\ \text { 4B } & 21.28 & 1.72 \\ \text { 5B } & 17.02 & 1.32 \\ \text { 6B } & 21.76 & 1.62\end{array}$

Extracted nuclei were stained in dinitrofluorobenzene and the total protein, in seven B chromosome classes (0-6B), was estimated by microspectrophotometry. Fifty nuclei were measured in each class and the means are shown in table 10 and in fig. 6 . The figure shows a clear inçrease with increasing B frequency. An analysis of variance, table 11 , confirms significant differences between classes $(P=<0.001)$. Figure 6 shows that the 


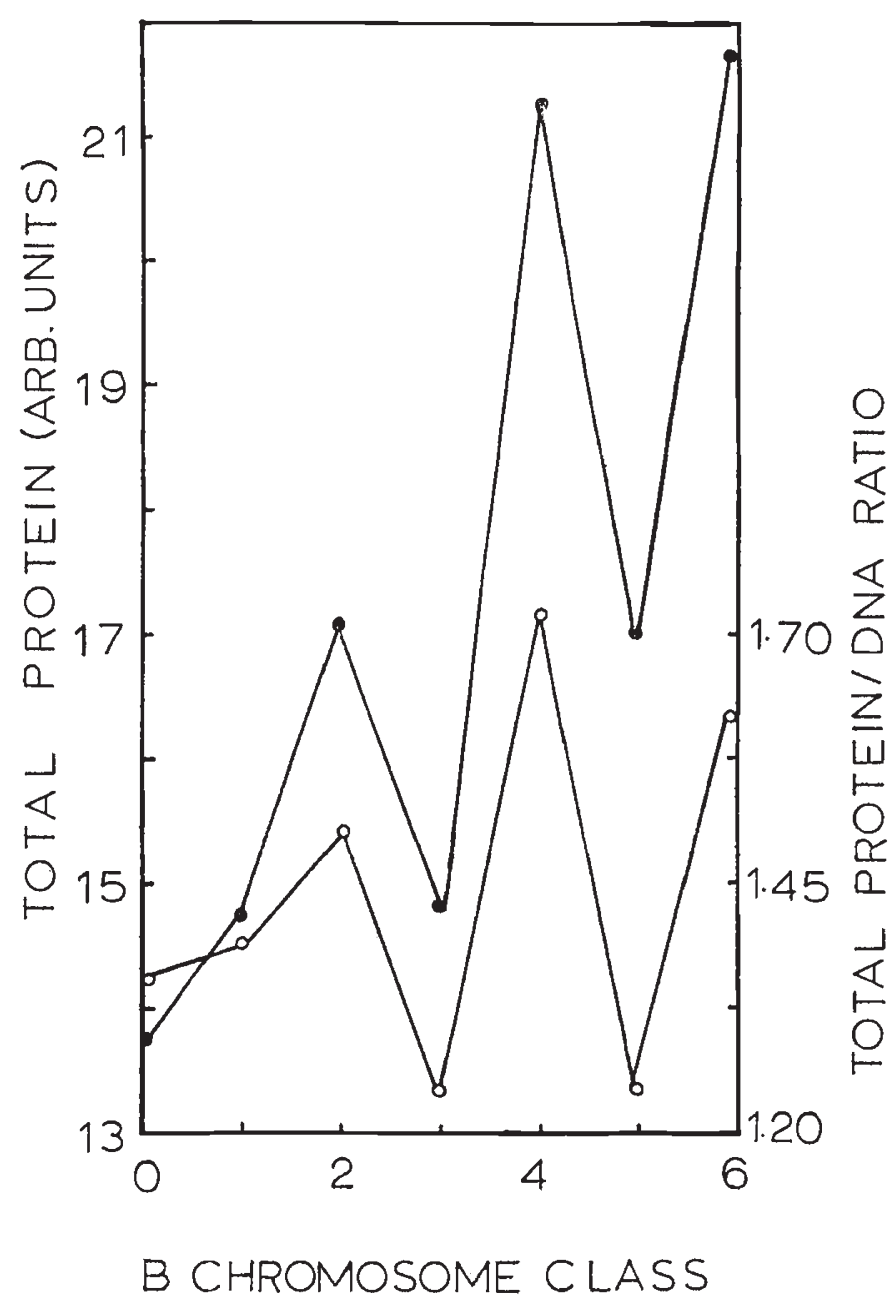

Fig. 6.-Total protein amounts in arbitrary units protein/DNA ratios $\mathrm{O} \longrightarrow \mathrm{O}$ in the $\mathrm{B}$ chromosome classes of maize.

TABLE 11

Analysis of variance of differences in total protein in seven B chromosome classes of maize

$\begin{array}{lcrccc}\text { Item } & \text { S.S. } & \text { d.f. } & \text { M.S. } & \text { V.R. } & \text { P } \\ \text { Classes } & 3053.794 & 6 & 508.97 & 29.83 & <0.001 \\ \text { Error } & 5851.980 & 343 & 17.06 & - & - \\ \text { Total } & 8905.774 & 349 & - & - & -\end{array}$

total protein/DNA ratio also increases with increasing $B$ frequency. However, the difference between the $\mathrm{B} 4$ and $6 \mathrm{~B}$ classes is small and it is possible that the increase in total protein is not maintained indefinitely with higher B numbers.

Some of the increase in protein content is no doubt attributable to the "permanent" protein component of the B chromosomes themselves. 
Since, however, the increase in protein is not consistently and directly proportional to the frequency of B's and, in particular, disproportionately variable between odd and even numbers of B's, it is equally clear that much of the protein variation is attributable to changes in the "non-permanent" products of nuclear metabolism-a variation clearly profoundly influenced by $\mathrm{B}$ chromosomes.

That the variation in total nuclear protein concerns non-permanent, indeed extra chromosomal material is reinforced by the observation that the size (volume) of chromosomes is not affected by the B frequency (section i). The increase in nucleolar size, and mass, suggests that some of this protein material may be located in the nucleolus.

In the following section an account is given of the variation in one particular component of the nuclear protein, namely histone. The histones are of special interest, in view of the regulatory function attributed to them (Stedman and Stedman, 1950; Allfrey and Mirsky, 1963; Bonner, Ru-Chin and Gilden, 1963).

\section{(vi) Histone protein}

Extracted interphase nuclei were stained with fast green F.C.F. at a $p \mathrm{H}$ of between $8 \cdot 0$ and $8 \cdot 1$. At this $p \mathrm{H}$ range fast green is a specific stain for

TAble 12

Histone amounts (arb. units) in nine B chromosome classes of maize and their corresponding histone/DNA ratios

$\begin{array}{cccccc}\text { B class } & \text { Replicate } 1 & \text { Replicate 2 } & \text { Replicate } 3 & \text { Mean } & \begin{array}{c}\text { Histone/DNA } \\ \text { ratio }\end{array} \\ \text { OB } & 9.33 & 9 \cdot 30 & 7.83 & 8.82 & 0.87 \\ \text { 1B } & 9.55 & 10.00 & 10.00 & 9.85 & 0.91 \\ \text { 2B } & 9.45 & 9.52 & 9.45 & 9.47 & 0.84 \\ \text { 3B } & 11.20 & 10.82 & 11.43 & 11.15 & 0.94 \\ \text { 4B } & 10.30 & 10.80 & 10.50 & 10.53 & 0.85 \\ \text { 5B } & 12.75 & 13.03 & 13.03 & 12.94 & 0.99 \\ \text { 6B } & 12.35 & 12.67 & 12.98 & 12.67 & 0.94 \\ \text { 7B } & 15.12 & 13.95 & 14.00 & 14.36 & 1.02 \\ \text { 8B } & 13.18 & 13.50 & 13.20 & 13.29 & 0.91\end{array}$

histones. Photometric measurements at $645 \mathrm{~m} \mu$ were made on the nine B chromosome classes (0-8B) with three replicates (roots) in each class. Thirty nuclei were measured at random in each replicate. The data are presented in table 12 and fig. 7. Also shown are the histone/DNA ratios for

TABLE 13

Analysis of variance of differences in histone amounts in nine B chromosome classes of maize

\begin{tabular}{|c|c|c|c|c|c|}
\hline Item & S.S. & d.f. & M.S. & V.R. & $P$ \\
\hline Classes & $443 \cdot 74$ & 8 & $55 \cdot 47$ & $320 \cdot 64$ & $<0.001$ \\
\hline Error & $3 \cdot 12$ & 18 & $0 \cdot 173$ & - & - \\
\hline Total & $446 \cdot 86$ & 26 & - & - & - \\
\hline
\end{tabular}

the nine $B$ classes. It is clear from the table and the figure that the amount of histone increases with increasing $B$ frequency and an analysis of variance on the replicate means, table 13 , confirms significant differences between classes $(\mathrm{P}=<0.001)$. The increase in histone amounts is not, however, 
directly proportional to B class. In the odd-numbered B classes, $1 \mathrm{~s}, 3 \mathrm{~s}, 5 \mathrm{~s}$ and $7 \mathrm{~s}$, there is a disproportional increase. The same is true of the histone/ DNA ratios. It could of course be argued that low histone values for oddnumbered B plants reflect simply a lower proportion of stainable histone in their nuclei and that the total histone does not vary. There are no grounds, however, to substantiate this view.

Reports by Prescott (1966) and Robbins and Borun (1967) show that the synthesis of DNA and histones are closely coupled events and it has been reported that the ratio of histone to DNA remains constant throughout the

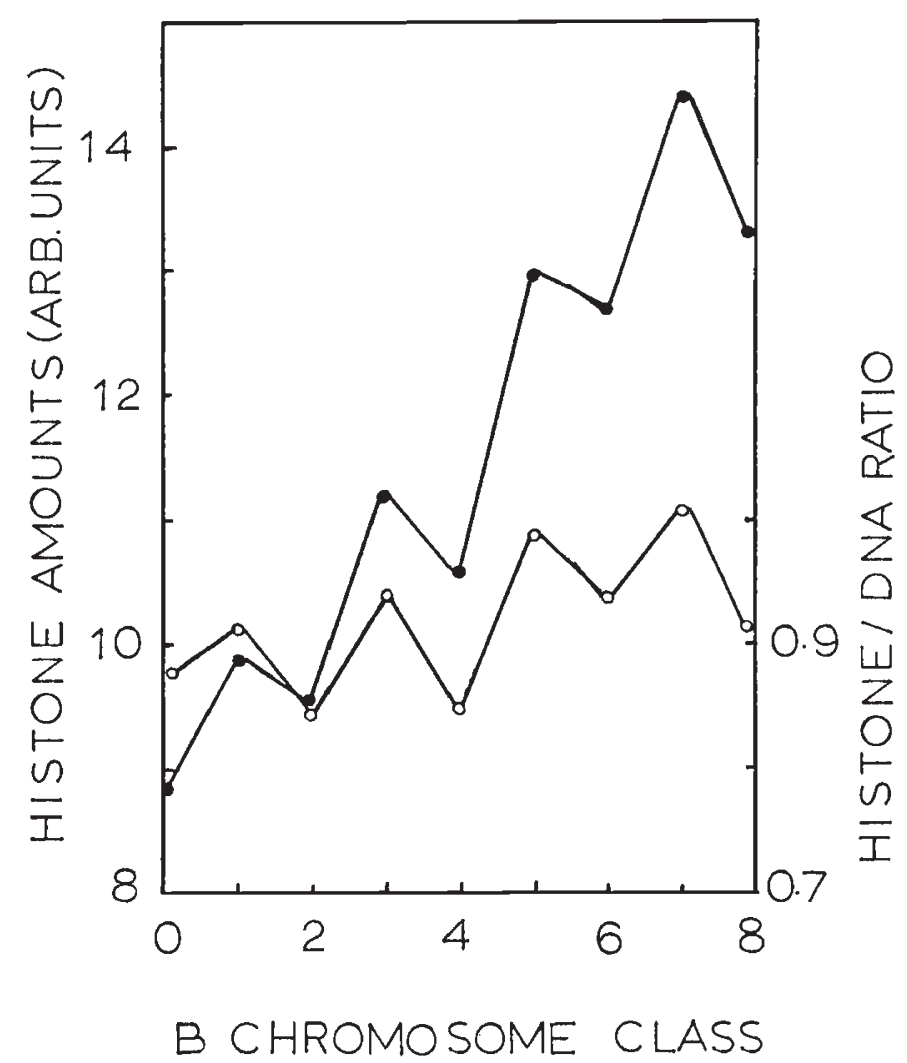

FIG. 7. - The amount of histone in arbitrary units - and the corresponding histone/ DNA ratios $\mathrm{O}-\mathrm{O}$ in nine $\mathrm{B}$ chromosome classes of maize.

life-cycle (Hancock, 1969; cf. Asao, 1969). However, the present work shows that the ratio of histone to DNA does vary between the nuclei of different genotypes, i.e. with the addition of B chromosomes (cf. Himes, 1967). Identical results have been obtained in rye and it is significant that those B classes in rye which "suffer" most from the presence of supernumerary chromosomes, the odd-numbered classes, are those with disproportionately high histone/DNA ratios (cf. Kirk and Jones, 1970). Whilst in maize we have no detailed information on the effect of different numbers of B's on the external phenotype it is worth emphasising that the nuclear RNA content of the odd B classes, i.e. those with high histone, is disproportionately low as in the east vigorous odd-numbered rye $\mathrm{B}$ classes. 


\section{(vii) Odds and evens}

A striking feature of B chromosomes in rye was their differential effects upon the phenotype when present in even as against odd numbers in the nucleus (Jones and Rees, 1968). For example, the variation in tiller number and plant weight, when plotted against B frequency, gave zig-zag patterns with disproportionately low tiller numbers and plant weights for oddnumbered B classes. Kirk and Jones (loc. cit.) have demonstrated that in parallel with the depression in tiller number and in plant weight in rye with odd $\mathrm{B}$ frequencies there is a reduction in total protein and RNA, an increase in histone in interphase nuclei; and vice versa for plants with even numbers of B's. The present results in maize are in complete agreement in showing disproportionately low RNA and total protein and disproportionately high histone amounts in odd-numbered B classes.

The mechanism for the differential activity of B's in even as compared to odd frequencies remains conjectural (see Jones and Rees, 1969). Considered together, the results from rye and maize provide compelling evidence to suggest, however, that the non-disjunction which encourages even numbers of B's in gametes and amongst progenies of B plants in numerous species is no mere accident but, rather, an adaptive device ensuring a preponderance of those phenotypes displaying greatest competence or "vigour", namely plants with even B frequencies.

\section{Discussion}

The effects of B chromosomes upon the external phenotype in maize have been described by Randolph (1941) and Roman (1947). Our investigation has been concerned with their effects, more, directly, upon the nuclei which bear them. In this respect the inquiry relates to a genotypic control exercised by the B's. Previous results established the effects upon the nuclear phenotype at meiosis (Ayonoadu and Rees, 1968). It was shown that they profoundly affect the frequency and distribution of chiasmata and, hence, genetic recombination. The present work reveals a genotypic control exercised by the B's upon somatic nuclei of which to date there are comparatively few examples (Rees, 1955). The control, furthermore, has a bearing upon growth and development of the whole plant.

Certain of the phenotypic changes imposed by B's upon nuclei are worth emphasis. One, in particular, is the negative correlation between, on the one hand, nuclear histone amount and, on the other hand, the total protein and RNA content. The correlation is completely in keeping with the regulatory " masking" role attributed to nuclear histone (Stedman and Stedman, 1950; Bonner et al., 1963; Berlowitz, 1965; Paul and Gilmour, 1968; Georgiev, 1969). We appreciate, of course, that these results tell us nothing about the mechanism by which such regulation could be achieved.

It would be wrong to oversimplify and assume direct causal relations between changes in the phenotype of the nucleus and that of the whole plant. At the same time the weight of evidence in rye, along with maize and Lolium (Williams, 1970), justifies emphasis upon the correlation between nuclear change due to B's and their regulatory effects upon growth and development. In a wider context it is clearly of interest to inquire whether comparable diversity in growth and development, but attributable to genetic 
causes other than the effects of B's, is accompanied by similar changes in nuclear composition to those we have described.

\section{Summary}

Studies on the effects of B chromosomes on the nuclear phenotype in root meristems of maize show that:

1. B chromosomes have no significant effect upon the size of A chromosomes.

2. Each B chromosome increases the nuclear DNA content by about 5 per cent.

3. B chromosomes at metaphase of mitosis have 1.7 times as much DNA per unit volume as A chromosomes.

4. The total dry mass of interphase nuclei increases with increasing $B$ frequency up to $4 \mathrm{~B}$ and thereafter decreases.

5. Total protein and the nuclear RNA content also increase up to $4 \mathrm{~B}$. The RNA decreases in amount beyond $4 \mathrm{~B}$.

6. The histone content shows a continuing increase with increasing $B$ frequency.

7. The general trends in respect of dry mass, RNA, total protein, and histone protein is complicated by a differential variation between odd and even numbered B plants-a phenomenon first reported in rye. The dry mass, nuclear RNA, and total protein are disproportionately high in evennumbered $B$ plants while the reverse is true for histone protein.

8. The regulatory role of $B$ chromosomes upon the genetic activity of the nucleus is briefiy discussed.

\section{REFERENGES}

ABRAhAM, s., AND SMTTH, H. H. 1966. DNA synthesis in B chromosomes of maize. Four. Heredity, 57, 78-80.

ALFERT, M., AND GESHWIND, I. I. 1953. A selective staining method for the basic proteins of cell nuclei. Prot. nat. Acad. Sci., 39, 991-998.

ALLFREY, v. G., AND MIRSKY, A. E. 1963. Mechanisms of synthesis and control of protein and ribonucleic acid synthesis in the cell nucleus. Brookhaven Symp. Quant. Biol., 28, 247-262.

ASAO, T. 1969. Behaviour of histones and cytoplasmic basic proteins during embryogenesis of the Japanese newt, Triturus pyrrhogaster. Exp. Cell. Res., 58, 243-252.

Avdulow, N. P. 1933. On the additional chromosomes in maize. Bull. Appl. Bot. Ser., 2, $101-130$.

AYONOADU, U. W., AND REES, H. 1968. The influence of B chromosomes on chiasma frequencies in black Mexican sweet corn. Genetics, 39, 75-81.

BACHMAN, K., AND COWDEN, R. R. 1965. Quantitative cytophotometric studies in isolated liver nuclei of Bullfrog, Rana catesbeiana. Chromosoma (Berl.), 17, 22-34.

BARER, R. 1956. The interference microscope in quantitative cytology. Suppl. to Baker. Interference Microscope, 2nd ed. London and Croydon: C. Baker (London).

BENNETT, M., AND REES, H. 1969. Induced and developmental variation in chromosomes of meristematic cells. Chromosoma (Berl.), 27, 226-244.

BERLOWTTZ, L. 1965. Correlation of genetic activity, heterochromatization and RNA metabolism. Proc. nat. Acad. Sci., 53, 68-75.

BLACKWOOD, M. 1956. The inheritance of B chromosomes in Zea mays. Heredity, 10, 353-366. BONNER, I., HUANG, R-C. C., AND GILDEN, R. v. 1963. Chromosomally directed protein synthesis. Proc. nat. Acad. Sci., 50, 893-900.

BRINK, R. s. 1958. Paramutation at the $\mathbf{R}$ locus in maize. Cold spring Harb. Symp. Quant. Biol., 23, 379-391. 
BROWN, R. 1963. Protein synthesis during cell growth and differentiation. Brookhaven Symp. Biol., 16, 58-94.

BUSCH, H., STARBUCK, W. C., SINGH, E. J., AND RO, 1. s. 1964. Chromosomal proteins. In The Role of Chromosomes in Development (M. Lock, ed.), pp. 51-69. New York: Acad. Press.

CAsPersson, T. 1947. The relations between nucleic acid and protein synthesis. Symp. Soc. exp. Biol., 1, 127-151.

CAspersson, т. 1950. Cell Growth and Cell Function, 185 pp. New York: Norton.

DARLington, C. D. 1965. Cytology. London: J. and A. Churchill.

DARLINGtoN, C. D., AND UPCOTT, M. B. 1941. The activity of inert chromosomes. F. Genet. $41,275-297$.

DAVIES, H. G. 1958. The determination of mass and concentration by microscope interferometry. In General Cytochemical Methods, vol. 1. New York and London: Acad. Press Inc.

Dowrick, G. J. 1952. The chromosomes of Chrysanthemums. 1. The species. Heredity, 6, 365-376.

EVANS, G. M. 1968. Nuclear changes in flax. Heredity, 23, 25-38.

GEORGIEV, G. P. 1969. Histones and the control of gene action. Ann. Rev. Genet., 3, 155-180.

HANCOCK, R. 1969. Conservation of histones in chromatin during growth and mitosis in vitro. 7. Mol. Biol., 40, 457-466.

HiмEs, м. 1967. An analysis of heterochromatin in maize root tips. F. cell Biol., 35, 175181.

hOAGLAND, D. R. 1920. In Introduction to Plant Physiology, by Curtis and Clark, p. 384. McGraw-Hill Book Co. Inc., 1950.

HUMPHREY, L. M. 1935. Chromosome studies in black Mexican maize. 1. Behaviour of extra chromosomes in black Mexican inbred lines and hybrids with dent types of maize. Iowa S. College J. Sci., 9, 549-557.

KIRK, D., AND JONES, R. N. 1970. Nuclear genetic activity in B chromosome rye, in terms of the quantitative interrelationships between nuclear protein, nuclear RNA and histone. Chromosoma, 31, 241-254.

JONES, R. N., AND REES, H. 1968. The influence of B chromosomes upon the nuclear phenotype in rye. Chromosoma (Berl.), 24, 158-168.

JONES, R. N., AND REES, H. 1969. An anomalous variation due to B chromosomes in rye. Heredity, 24, 265-271.

kоzhuchow, z. A. 1933. Über die Natur der Extrachromosomen bei Zea mays L. Planta, 19, 91-116.

kuWADA, צ. 1915. Uebier dies Chromosomenzahl von Zea mays L. Bot. Mag. (Tokyo), 29, 83-89.

LEUCHTENBERGER, C., AND SCHRADER, F. 1952. Variation in the amounts of DNA in cells of the same tissue and its correlation with secretory function. Proc. nat. Acad. Sci., 50, 99105.

LEWIS, E. B. 1950. The phenomenon of position effect. Adv. Genet., 3, 73-115.

LiN, M. 1955. Chromosomal control of nucleolar composition in maize. Chromosoma (Berl.), 1, 340-370.

LONGLEy, A. E. 1927. Supernumerary chromosomes in Zea mays. 7. Agric. Res., 28, 673-682.

LONGLEY, A. E. 1938. Chromosomes of maize from North American Indians. F. Agric. Res., $56,177-195$.

mather, x. 1944. The genetical activity of heterochromatin. Proc. roy. Soc., B, 132, 308332.

мCCLnNTOCK, в. 1950. The origin of mutable loci in maize. Proc. nat. Acad. Sci., 36, 344-355.

MCLEISH, J. 1963. Quantitative relationships between deoxyribonucleic acid and ribonucleic acid in isolated plant nuclei. Proc. roy. Soc. Lond., B, 158, 261-275.

MCLEISH, J., AND SUNDERLAND, N. 1961. Measurements of deoxyribonucleic acid (DNA) in higher plants by Feulgen photometry and chemical methods. Exp. Cell Res., 24, 527-540.

MiTCHEL, J. P. 1967. Combined protein and DNA measurements in plant cells using the dinitrofluorobenzene and Feulgen techniques. 7. roy. micro. Soc., 87, 375-381.

MOss, G. 1. 1967. A cytochemical study of DNA, RNA and protein in the developing maize anther. Ann. Bot. Lond., 31, 545-553.

MUNTZING, A. 1943. Genetical effects of duplicated fragment chromosomes in rye. Hereditas, $29,91-112$.

mUNTZING, A. 1954. Cyto-genetics of accessory chromosomes (B chromosomes). Caryologia, Suppl. 6, 282-301. 
muntzing, A. 1963. The effects of accessory chromosomes in diploid and tetraploid rye. Hereditas, 49, 371-426.

PAUL, G., AND GILMOUR, R. s. 1968. Organ-specific restriction of transcription in mammalian chromatin. 7. Mol. Biol., 34, 305-316.

PRESCOTT, D. M. 1966. The synthesis of total macronuclear potein, histone and DNA during the cell cycle in Euplotes eurystomus. 7. Cell Biol., 31, 1-9.

RANDolPh, L. F. 1928. Chromosome number in Zea mays L. Cornell Agric. Exp. Sta. Mem., 117. $44 \mathrm{pp}$.

RANDOLPH, L. F. 1941. Genetic characteristics of B chromosomes in maize. Genetics, 26, 608-631.

REES, H. 1955. Genotypic control of chromosome form and behaviour. Bot. Rev., 27, 288318.

RICHARDS, B. M. 1960. Redistribution of nuclear proteins during mitosis. In The Cell Nucleus (J. S. Mitchell, ed.). London: Butterworths.

ROBBINS, E., AND BORUN, T. W. 1967. The cytoplasmic synthesis of histones in HeLa cells and its temporal relationship to DNA replication. Proc. nat. Acad. Sci., 57, 409-416.

ROMAN, H. 1947. Mitotic non-disjunction in the case of interchanges involving B-type chromosomes in maize. Genetics, 32, 391-409.

sharma, v. B. 1965. Genetic systems in Allium. III. Meiosis and breeding systems. Heredity, 20, 235-339.

stedman, E., AND STEDMAN, E. 1950. Cell specificity of histones. Nature, 166, 780-781.

SUNDERLAND, N., AND MCLEISH, J. 1961. Nucleic acid content and concentration in root cells of higher plants. Exp. Cell Res., 24, 541-554.

SWIFT, н. 1953. Quantitative aspects of nucleo-proteins. Intern. Rev. Cytol., 2, 1-76.

VAN SCHAIK, N., AND PITOUT, M. J. 1966. DNA from maize with B chromosomes. Maize Genetics Co-operation Newsletter, 40, 123-125.

VAN'T HOF, J. 1965. Relationships between mitotic cycle duration, S period duration and the average rate of DNA synthesis in the root meristem cells of several plants. Exp. Cell Res., 39, 48-58.

williams, P. 1970. Ph.D. Thesis, University of Wales. 